Annals of Plant and Soil Research 23(1): 23-29(2021)

https://doi.org/10.47815/apsr.2021.10024

\title{
Application of geo-spatial technologies in soil suitability assessment for village level crop planning in Chittaurgarh, Rajasthan
}

\author{
RAMESHWAR SINGH ${ }^{1}$, T.P. VERMA ${ }^{2}$, R.S. SINGH ${ }^{3}$, B.L. TAILOR, S.S. SHARMA ${ }^{4}$, M.K. JAT ${ }^{5}$, \\ A.K. SINGH ${ }^{6}$, M. NOGIYA AND P.C. MOHARANA
}

National Bureau of Soil Survey and Land Use Planning, Regional Centre, Udaipur-313001 (Rajasthan)

Received: August, 2020; Revised accepted: October, 2020

\begin{abstract}
The agro-eco-sub region (AESR) 4.2 encompasses Aravalli foot hills, central Rajasthan plains and adjoining areas. Visual interpretation of geo-coded satellite data (IRS-P6, LISS IV MX) on the same scale was done before starting the field work. Based on the interpretative units a high intensity detailed soil survey was carried out in cluster of ten villages of Bhadesar tehsil of Chittaurgarh district on cadastral map (1:4000 scale) and the soils were characterized with respect to landforms. In all, 14 soil series were established and assessed for soil site suitability for maize, wheat, mustard and soybean. Daulatpura-c series soils are suitable for maize, mustard, soybean, and Daulatpura-d soils for soybean and moderately suitable for other crops. Soils of Bagund and Narbadiya-a series are moderately suitable for maize and marginally suitable for other crops. The soils of Bhadsoda-b series are marginally suitable only for mustard but moderately suitable for all other crops. Soils of Parliya series are moderately suitable only for mustard crop and marginally suitable for remaining crops. The soils of Guda series are marginally suitable for maize, wheat, mustard but not suitable for soybean. The soils of Nardhari-a and Nardhari-b are moderately suitable, Daulatpura-b, Bhadsoda-a and Narbadiya-b are marginally suitable whereas soils of Madanpura and Daulatpura are not suitable for all the crops due to limitations of shallow soil depth.
\end{abstract}

Key words: Soil suitability assessment, crop planning, hot-moist semi-arid region, Rajasthan

\section{INTRODUCTION}

Land use planning is a systematic assessment of physical, social and economic factors to encourage and support land user in selecting options, which increase productivity and sustainability of lands. Soil site suitability provides information on the choice of crops to be grown on best soil unit for maximizing crop production per unit of land, labour and inputs. Further, detailed soil survey provides the information necessary to identify homogeneous management units in the field to develop different cropping models according to their soil information and agronomic practices. Management of soil resources on scientific basis is very essential to maintain present level of soil production and soil degradation. In the recent years major emphasis has been given on soilsite characterization and developing rational and scientific criteria for land evaluation and interpretation of soils for diversified land uses. Therefore, it is very essential to know the spatial extent, physico-chemical characteristics, taxonomic distribution, limitations and potentials of soils for developing proper land use plan of the area. Remote sensing and GIS technology have emerged as powerful tool for studying soil resources in spatial domain in time and costeffective manner. Bhadesar tehsil is the maizewheat growing area of Chittaurgarh district and contributing major share of maize and wheat production of the Rajasthan state. Assessment of land suitability for crops can enhance the agricultural productivity of the area manifold. This may be achieved by developing cluster wise crop plan for sustainable land use planning of the area by using modern technologies like remote sensing and GIS. Soil resource information and land use planning options for village level crop planning are very scanty. Therefore, systematic and site-specific land resource information must be generated to develop land use plan for cluster of ten village.

\section{MATERIALS AND METHODS}

\section{Study area}

The study was conducted in clusters of ten villages in Bhadesar tehsil of Chittaurgarh district Rajasthan. The area lies between $24^{\circ} 41^{\prime} 14.5^{\prime \prime}$ to $24^{\circ} 45^{\prime} 11.6^{\prime \prime} \mathrm{E}$ latitudes and $74^{\circ} 20^{\prime} 16.4^{\prime \prime}$ to $74^{\circ} 26^{\prime} 34.4^{\prime \prime} \mathrm{N}$ longitudes and occupying about $5160 \mathrm{ha}$. The elevation of the study area is 540-

$542 \mathrm{~m}$ above mean sea level

\section{${ }^{*}$ Corresponding authors email: rssnbss@gmail.com}

${ }^{1}$ Assistant Scientist CCSHAU, RRS, Bawal, Rewari - 123401 Hrayana, ${ }^{2}$ Principal Scientist \& Head, ICAR-NBSS\&LUP, $R C$, New Delhi, ${ }^{3}$ ExPrincipal Scientist \& Head, ICAR-NBSS\&LUP, RC, Udaipur, ${ }^{4}$ Assistant Professor, SKNAU, Jobner,

${ }^{5}$ Assistant Scientist CCSHAU, RRS, Bawal, ${ }^{6}$ Principal Scientist ICAR-IIMR, Ludhiana 
(MSL). The climateof the area is semi-arid moist and monsoonic type with mean annual rainfall of $886 \mathrm{~mm}$ and about $95 \%$ of the annual rainfall received during June to September. Mean annual soil temperature is $30.1^{\circ} \mathrm{C}$; the mean annual summer and mean winter soil temperatures are $36.2^{\circ} \mathrm{C}$ and $21.2^{\circ} \mathrm{C}$, respectively. The length of growing period (LGP) of the area varies from 105-130 days. Soil moisture and soil temperature regimes of the study area are ustic and hyperthermic, respectively.

\section{Soil mapping}

The detailed soil survey of the villages was carried out by using cadastral maps. Since the scale of the maps available is uniform for all the villages (1:4000 scale) and reduced to a uniform scale of $1: 12,500$ with precision geo-coded satellite data (IRS-P6, LISS IV MX) on same scale before starting the field work.Apart from the cadastral maps of 10 villages and imageries, survey of India (SOI) toposheets at 1:50,000 scale have been used as a base for initial traversing, identification of geology, landforms, drainage features, present land use and for the selection of transects at tehsil level for preparation of preliminary legend to establish good soil-physiographic relationship in the area. The geo-coded satellite data were visually interpreted based on image elements like tone, texture, pattern, and shape of the features. The field investigation was carried out in the whole area by intensive traversing of each physiographic unit like ridge, uplands, valleys and plain etc. Based on the variability observed on the surface, transects were selected across the slope, covering all the physiographic units to identify sites for soil profile examination. The soil and site characteristics have been recorded for all the profile sites as per the guidelines given in USDA Soil Survey Manual (Soil Survey Division Staff 2000). At each site, latitude, longitude and altitude were also recorded with the help of hand held GPS. Based on the soil-site characteristics recorded during soil survey, the soils were grouped into different soil series through soil correlation. After grouping the soils into different soil series, the phases of soil series were identified by intensive field traversing, checking thoroughly for variability in surface texture and the boundaries of soil mapping units were delineated on the base maps (IARI 1971).
Besides this, 190 surface soil samples were also collected from different mapping units and analyzed for physical and chemical properties in laboratory as per standard procedures (Jackson 1973). The soils were classified into the subgroups of Inceptisols, Vertisols and Entisols orders (Soil Survey Staff 2014).Laboratory data were processed in GIS environment using Arc GIS 10.3 and thematic maps were generated for soil site suitability of each crop.

\section{RESULTS AND DISCUSSION}

The slope varied from $1-3 \%$ in gently sloping upland and nearly level to gently sloping plain whereas it was $8-15 \%$ in gently sloping to undulating hillocks landform (Table 1). Most of the soils having very slight to moderate erosion but very severe erosion was observed in the soils of gently sloping to undulating hillocks landform. Most of the soils were moderately well drained.The soils of series varied from very shallow to deep having sandy cay loam to clay loam texture. The $\mathrm{pH}$ of soil varied from 7.5 to 8.2 whereas electrical conductivity ranged from 0.08 to $0.23 \mathrm{dS} / \mathrm{m}$. The organic carbon content of the soils varied from 0.39 to 0.94 per cent and decreased with depth. The cation exchange capacity (CEC) of the soils ranged from 15.2 to $34.30 \mathrm{cmol}(p+) \mathrm{kg}^{-1}$ soil.

\section{Land capability classification(LCC)}

The land capability classes (LCC) and their extent in the watershed are presented in Table 2. Land capability class II occupied highest area (41\%) followed by class III (39\%), class V $(14 \%)$ and least area by class IV (3\%). Land capability class II have major problem of fine soil texture which mostly occurs in Bhadsoda, Narbadiya, Parliya, Sohankhera and Bagund villages covering about $75 \%$ area of this class. Land capability class III having major problems of erosion, gravelliness, salinity-sodicity, fine texture, and shallow depth occurring in Parliya, Bhadsoda, and Narbadiya villages and covering about $75-85 \%$ area of this class. Land capability class $\mathrm{V}$ having problems regarding erosion, gravelliness and shallow depth occurring in Bagund, Parliya and Narbadiya villages and covering about $73 \%$ area of this class. Land capability class IV having major constraint of salinity and sodicity in Bhadsoda, Bagund, 
Table1: Soil-site characteristics of cluster of ten villages in Bhadesar tehsil for land evaluation

\begin{tabular}{|c|c|c|c|c|c|c|c|c|c|c|c|}
\hline \multirow[b]{2}{*}{ Soil series } & \multicolumn{2}{|c|}{$\begin{array}{c}\text { Climatic } \\
\text { characteristics (c) }\end{array}$} & \multicolumn{3}{|c|}{ Site characteristics } & \multicolumn{6}{|c|}{ Physico-chemical characteristics (f) } \\
\hline & $\begin{array}{c}\text { Rainfall } \\
(\mathrm{mm})\end{array}$ & $\begin{array}{l}\text { LGP } \\
\text { (days) }\end{array}$ & $\begin{array}{c}\text { Slope } \\
(\%)\end{array}$ & $\begin{array}{c}\text { Erosion } \\
(\mathrm{e})\end{array}$ & $\begin{array}{l}\text { Drainage } \\
\text { (w) }\end{array}$ & $\begin{array}{l}\text { Depth } \\
(\mathrm{cm})\end{array}$ & Texture & $\mathrm{pH}$ & $\begin{array}{c}\mathrm{EC} \\
\left(\mathrm{dS} \mathrm{m}^{-}\right. \\
1)^{-}\end{array}$ & $\begin{array}{l}\mathrm{OC} \\
(\%)\end{array}$ & $\begin{array}{c}\text { CEC } \\
{\left[\mathrm{cmol}^{(p+)}\right.} \\
\left.\mathrm{kg}^{-1}\right]\end{array}$ \\
\hline Madanpura & 885.6 & $105-130$ & $8-15 \%$ & Very severe & Moderate & $<25$ & $\mathrm{scl}$ & 7.9 & 0.09 & 0.46 & 21.5 \\
\hline Daulatpura- a & 885.6 & $105-130$ & $8-15 \%$ & Very severe & $\begin{array}{l}\text { Moderate } \\
\text { Somewhat }\end{array}$ & $25-50$ & $\mathrm{scl}$ & 8.0 & 0.16 & 0.54 & 19.0 \\
\hline Daulatpura- b & 885.6 & $105-130$ & $3-8 \%$ & Severe & $\begin{array}{l}\text { excessively } \\
\text { drained }\end{array}$ & $50-75$ & $\mathrm{sl}$ & 7.8 & 0.16 & 0.55 & 15.2 \\
\hline Bhadsoda- a & 885.6 & $105-130$ & $3-8 \%$ & Severe & Well & $25-50$ & $\mathrm{cl}$ & 8.2 & 0.08 & 0.76 & 25.0 \\
\hline Bagund series & 885.6 & $105-130$ & $1-3 \%$ & Moderate & Well & $25-50$ & I & 7.5 & 0.23 & 0.84 & 21.5 \\
\hline Narbadiya-a & 885.6 & $105-130$ & $1-3 \%$ & Moderate & Well & $25-50$ & $\mathrm{cl}$ & 7.8 & 0.23 & 0.94 & 30.0 \\
\hline Bhadsoda- b & 885.6 & $105-130$ & $3-8 \%$ & Severe & Well & $50-75$ & sl & 7.7 & 0.23 & 0.41 & 18.7 \\
\hline Daulatura-c & 885.6 & $105-130$ & $1-3 \%$ & Very slight & Well & $50-75$ & sl & 7.7 & 0.16 & 0. & 33.2 \\
\hline Nardhari-a & 885.6 & $105-130$ & $1-3 \%$ & Very slight & Well & $50-75$ & $\mathrm{cl}$ & 8.0 & 0.20 & 0.76 & 34.3 \\
\hline Nardhari-b & 885.6 & $105-130$ & $1-3 \%$ & Moderate & Well & $75-100$ & scl & 8.2 & 0.19 & 0.84 & 22.4 \\
\hline Daulatura-d & 885.6 & $105-130$ & $1-3 \%$ & Very slight & Moderate & $75-100$ & $\mathrm{cl}$ & 8.2 & 0.21 & 0.97 & 27.1 \\
\hline Guda & 885.6 & $105-130$ & $1-3 \%$ & Very slight & Moderate & $100-150$ & $\mathrm{scl}$ & 9.1 & 0.87 & 0.39 & 21.4 \\
\hline Narbadiya-b & 885.6 & $105-130$ & $1-3 \%$ & Very slight & Moderate & $100-150$ & 1 & 8.7 & 0.82 & 0.53 & 18.5 \\
\hline Parliya & 885.6 & $105-130$ & $1-3 \%$ & Very slight & Moderate & $100-150$ & $\mathrm{cl}$ & 8.7 & 0.46 & 0.90 & 28.0 \\
\hline
\end{tabular}

Parliya, Daulatpura, and Narbadiya villages and covering about $90 \%$ area of this class. The rating index between 2 and 3 was calculated in Bagund and Parliya villages indicating predominance ofland capability class III. Whereas, rating index between 3 and 3.3 in Bhadsoda, Daulatpura, Guda, Madanpura, Narbadiya, Nardhari, Sohankhera and Surajpura villages indicating predominance of land capability class II.

Table 2: Land capability and land irrigability classification of soils in cluster of tenvillages in Bhadesar tehsil

\begin{tabular}{|c|c|c|c|c|}
\hline S.No. & Soil Series & Mapping Unit & LCC & $\mathrm{LIC}$ \\
\hline 1. & Madanpura & 1.MdGdD3 & Ves & $4 \mathrm{st}$ \\
\hline 2. & Daulatpura-a & 2.DpaGcC3 & Ves & $4 s t$ \\
\hline & & 3.DpaGcD3 & Ves & $4 s t$ \\
\hline 3. & Daulatpura-b & 4.DpbgcC3 & IVes & $4 s t$ \\
\hline 4 & Bhadsoda-a & 5.BsaĞeC2 & IVes & $3 s t$ \\
\hline 5 & Bagund & $\begin{array}{l}\text { 6. BggcB2 } \\
\text { 7. BaGcB2 }\end{array}$ & $\begin{array}{l}\text { Illes } \\
\text { Illes }\end{array}$ & $\begin{array}{l}3 s t \\
3 s t\end{array}$ \\
\hline 6 & Narbadiya-a & 8.NbageB2 & Illes & $3 s t$ \\
\hline 7. & Bhadsoda-b & $\begin{array}{l}\text { 9. BsbcB2 } \\
\text { 10. BsbgcC2 }\end{array}$ & $\begin{array}{l}\text { Illes } \\
\text { Illes }\end{array}$ & $\begin{array}{l}3 s t \\
3 s t\end{array}$ \\
\hline 8. & Daulatpura-c & $\begin{array}{l}\text { 11.DpccB1 } \\
\text { 12.DpccB2 } \\
\text { 13.DpceB1 } \\
\text { 14.DpceC2 } \\
\text { 15.NdaeA1 }\end{array}$ & $\begin{array}{l}\text { Ils } \\
\text { Ils } \\
\text { Ils } \\
\text { Ils } \\
\text { Ils }\end{array}$ & $\begin{array}{l}2 s \\
2 s \\
2 s \\
2 s \\
2 s\end{array}$ \\
\hline 9. & Nardhari-a & $\begin{array}{l}\text { 16.NdaeB2 } \\
\text { 17.NdadB1 } \\
\text { 18.NdbdB1 }\end{array}$ & $\begin{array}{l}\text { Ils } \\
\text { Ils } \\
\text { Ils }\end{array}$ & $\begin{array}{l}2 s \\
2 s \\
2 s\end{array}$ \\
\hline 10. & Nardhari-b & $\begin{array}{l}\text { 19.NdbdC2 } \\
\text { 20.NdbeB2 } \\
\text { 21.DpdeA1 }\end{array}$ & $\begin{array}{l}\text { Ils } \\
\text { Ils } \\
\text { Ils }\end{array}$ & $\begin{array}{l}2 s \\
2 s \\
2 s\end{array}$ \\
\hline 11. & Daulatpura-d & $\begin{array}{l}\text { 22.DpdeB1 } \\
\text { 23.DpdeB2 }\end{array}$ & $\begin{array}{l}\text { Ils } \\
\text { Ils }\end{array}$ & $\begin{array}{l}2 s \\
2 s\end{array}$ \\
\hline 12. & Guda & 24.GjdB1 & IVs & $4 s d$ \\
\hline 13. & Narbadiya-b & $\begin{array}{l}\text { 25.NbbdB1 } \\
\text { 26.NbbdB2 } \\
\text { 27.PrdB1 }\end{array}$ & $\begin{array}{l}\text { Ills } \\
\text { Ills } \\
\text { Ills }\end{array}$ & $\begin{array}{l}3 s \\
3 s \\
3 s\end{array}$ \\
\hline 14. & Parliya & $\begin{array}{l}\text { 28.PreA1 } \\
\text { 29.PreB2 }\end{array}$ & $\begin{array}{l}\text { IIls } \\
\text { Ills }\end{array}$ & $\begin{array}{l}3 s \\
3 s\end{array}$ \\
\hline
\end{tabular}




\section{Land irrigability classification (LIC)}

Land irritability classification is the grouping of mapping units into land irritability classes and subclasses based on the degree of limitation observed in the land resources of the area for sustained use under irrigation (IARI, 1971). The criteria used for irritability classification are effective soil depth, surface soil texture, permeability, coarse fragments, slope, erosion, drainage and so on. In this system, there are 6 classes, of which, first four classes are considered to be irrigable lands with slight, moderate, severe and very severe limitations respectively (Table 2). Class 5 lands are treated as presently not suitable and class 6 land is considered permanently not suitable for irrigation. Land irritability classes identified were divided into sub-classes depending on the nature of the limitations for irrigation namely soil (s), topography (t) and drainage (d). The land irrigability classes 2, 3 and 4 have been occurred in the cluster of villages. The land irrigability class 2 have highest area $(41 \%)$ followed by class 3 (39\%), and class 4 (16\%). Land irrigability class 4 have major problems of slope, soil depth, coarse fragments and salinity-sodicity and occurs mostly in Parliya, Bagund, Bhadsoda, Narbadiya and Daulatpura villages covering about more than $75 \%$ area of this class.
Whereas, land irrigability class 2 have major constraint of fine texture which was identified in Bhadsoda, Narbadiya, Parliya, Sohankhera and Bagund villages covering about $76 \%$ area of this class. Land irrigability class 3 have major constraints pertaining to soil depth, slope and salinity-sodicity and occurs in Bhadsoda, Nardhari, Bagund, Madanpura and Sohankhera villages covering about $77 \%$ area of this class. Rating index between 2 and 3 in Bagund, Daulatpura, and Parliya villages indicating predominance of land irrigability class 3, whereas rating index between 3.1 and 3.6 in Bhadsoda, Guda, Madanpura, Narbadiya, Nardhari, Sohankhera and Surajpura villages indicating predominance of land irrigability class 2.

\section{Soil suitability for major crops}

\section{Maize (Zea mays L.)}

Soils of Daulatpura-c series rated as highly suitable which do not have any limitation regarding physical and chemical constraints (Table 1). Soils of Bagund, Narbadiya-a, Bhadsoda-b, Nardhari-a, Nardhari-b and Daulatpura-d rated as moderately suitable on account of shallow depth, low fertility and moderate slope (Table 3).

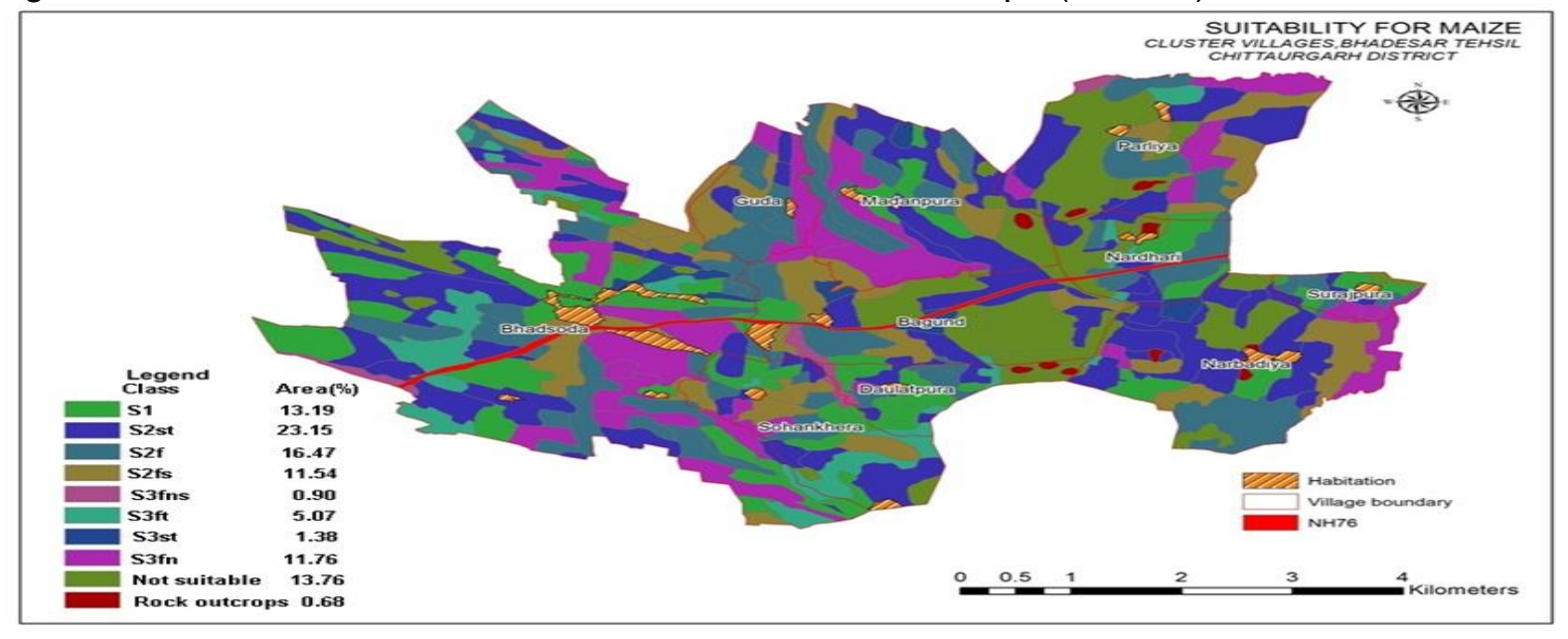

Fig.1 Soil suitability map for maize in cluster of Bhadesar tehsil

Soils of Daulatpura-b, and Bhadsoda-a, series are marginally suitable which have constraints regarding soil texture and low nutrient content. Gudha, Narbadiya-b andalkaline $\mathrm{pH}$ and slight salinity to moderateParliya series are also rated as marginally suitable due to strongly sodicity due to strongly sodicity problem besides this this these soils have moderate to high water holding capacity and slow permeability due to clay texture and low in nutrient status hence these soils are not suitablefor the cultivation of maize crop (Table 3). Madanpura and Daulatpura-a series rated as not suitable for maize cultivation due to severe 
erosion, gravelliness and very shallow to shallow depth of soil. Hegdeet al. (2019) also reported the similar results for soil-site suitability evaluation of maize crop. According to the assessment, $13 \%$ land is highly suitable, $51 \%$ land is moderately suitable, $19 \%$ land is marginally suitable and $14 \%$ land is unsuitable for maize cultivation in the cluster (Fig. 1).

\section{Wheat (Triticum vulgare)}

The computation of limitations as per Sys et al. (1993) indicated that Bhadsoda-b, daulatpura-c, Nardhari-a, Nardhari b, and Daulatpura-d are moderately suitable with medium nutrient status, generally moderate in depth and mainly clay loam in texture. Marginally suitable soils occur in Daulatpura-b, Bhadsoda-a, bagund, Narbadiyaa, Guda, Narbadiya-b and Parliya series (Table
3). Daulatpura-b and Bhadsoda-a series having limitations of severe erosion, shallow depth, moderate water holding capacity and nutrient retention are rated as marginally suitable. Soils of Madanpura and daulatpura-a series are also not suitable for wheat cultivation due to very severe limitations of erosion with strong stoniness, excessive relief, excessively drained with rapid permeability, shallow depth and loamy skeleton texture. Mustafa et al. (2016) and Gandhi and Savalia (2016) also presented similar results for soil suitability of wheat crop. The suitability evaluation indicated that $61 \%$ area is mapped in the cluster is moderately suitable, $23 \%$ is marginally suitable and rest $14 \%$ area is unsuitable for the cultivation of wheat (Fig. 2). Any improvement in these characteristics except texture may elevate the suitability to the next higher grade.

Table 3: Soil-site suitability for different crops grown in cluster of ten villages in Bhadesar tehsil

\begin{tabular}{|c|c|c|c|c|}
\hline Soil series & Maize & Wheat & Mustard & Soybean \\
\hline Madanpura & $\mathrm{N}$ & $\mathrm{N}$ & $\mathrm{N}$ & $\mathrm{N}$ \\
\hline Daulatpura-a & $\mathrm{N}$ & $\mathrm{N}$ & $\mathrm{N}$ & $\mathrm{N}$ \\
\hline Daulatpura-b & S3ft & S3stf & S3ft & S3tf \\
\hline Bhadsoda-a & S3st & S3st & S3st & S3st \\
\hline Bagund series & S2st & S3st & S3st & S3st \\
\hline Narbadiya-a & S2st & S3st & S3st & S3st \\
\hline Bhadsoda- b & S2st & S2fst & S3st & S2st \\
\hline Daulatura-c & S1 & S2s & S1 & S1 \\
\hline Nardhari-a & S2fs & S2fs & S2s & S2fs \\
\hline Nardhari-b & $\mathrm{S} 2 \mathrm{f}$ & S2fs & S2s & S2f \\
\hline Daulatura-d & S2f & S2fs & S2s & S1 \\
\hline Guda & S3fns & S3fns & S3fns & $\mathrm{N}$ \\
\hline Narbadiya-b & S3fn & S3fn & S3fn & S3fn \\
\hline Parliya & S3fn & S3fs & S2s & S3fn \\
\hline
\end{tabular}

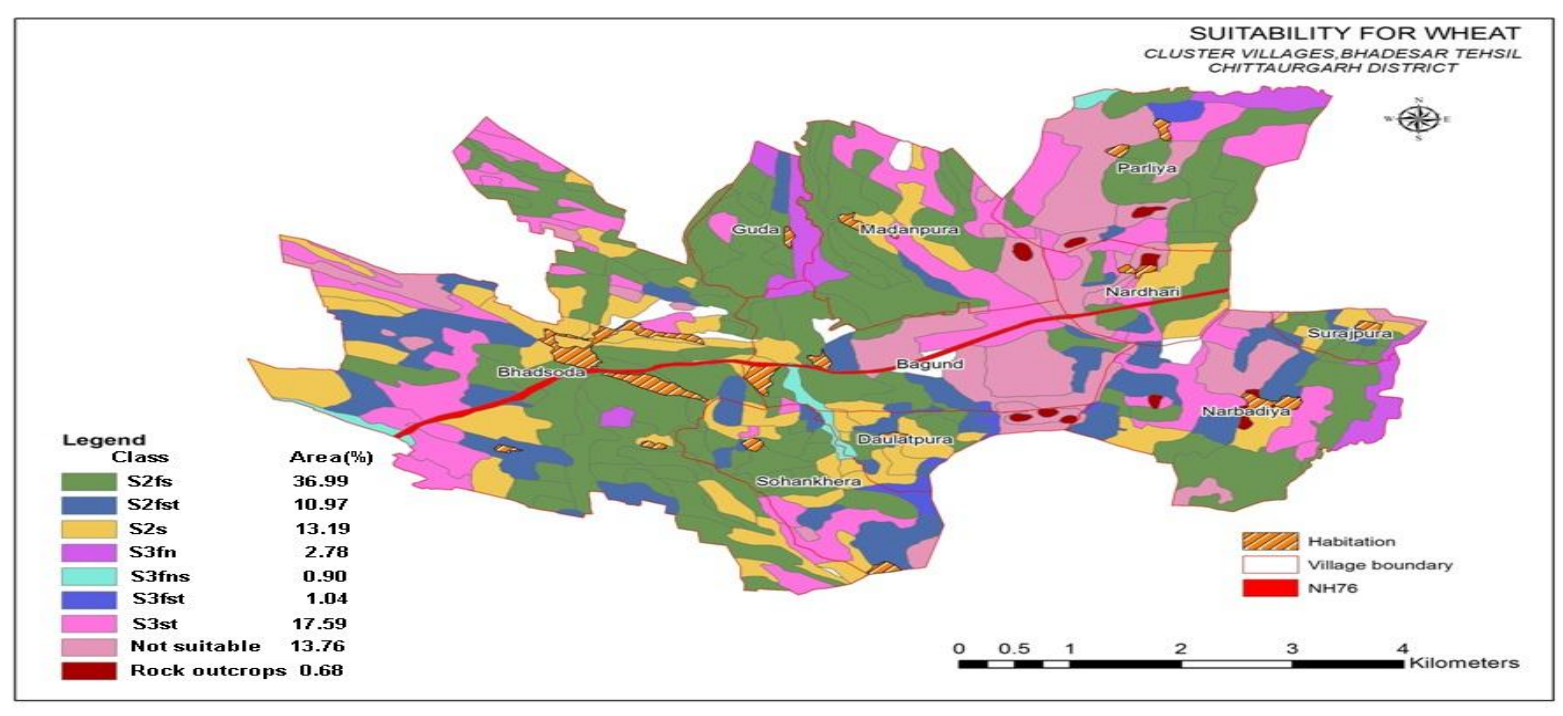

Fig.2. Soil suitability map for wheat in cluster of Bhadesar tehsil 


\section{Mustard(Brassica comprestis)}

Nardhari-a, Nardhari b, Daulatpura-d and Parlia series were moderately suitable soils due to physical constraints like slope and erosion (Table 3 ). Marginally suitable soils occur in Daulatpura-b, Bhadsoda-a, Bagund, Narbadiya-a, Bhadsoda-b Guda and Narbadiyab series. Gudha and Narbadiya-b series are rated as marginally suitable due to constraints of strongly alkaline $\mathrm{pH}$ and slight salinity to moderate sodicity problem and poor in nutrient status hence these soils are not suitable for the cultivation of mustard crop. Madanpura and daulatpura-a series are not suitable for mustard cultivation due to very severe limitations of erosion with strong stoniness, excessive relief, excessively drained with rapid permeability, shallow depth and loamy skeleton texture. Similar results were reported by Garhwal et al, (2013). It is revealed that about $13 \%$ area is highly suitable means has no any limitation for mustard cultivation (Fig. 3). About $51 \%$ of the study area represents the soils under moderately suitable class (S2) for mustard cultivation in the cluster. The major limitations in these soils are fertility, texture and slight salinity and slight sodicity. Marginally suitable soils occupy about $19 \%$ of area with major limitations of salinitysodicity, severe erosion, gravelliness, slope and soil depth. About 14\% area is unsuitable for the cultivation of mustard.

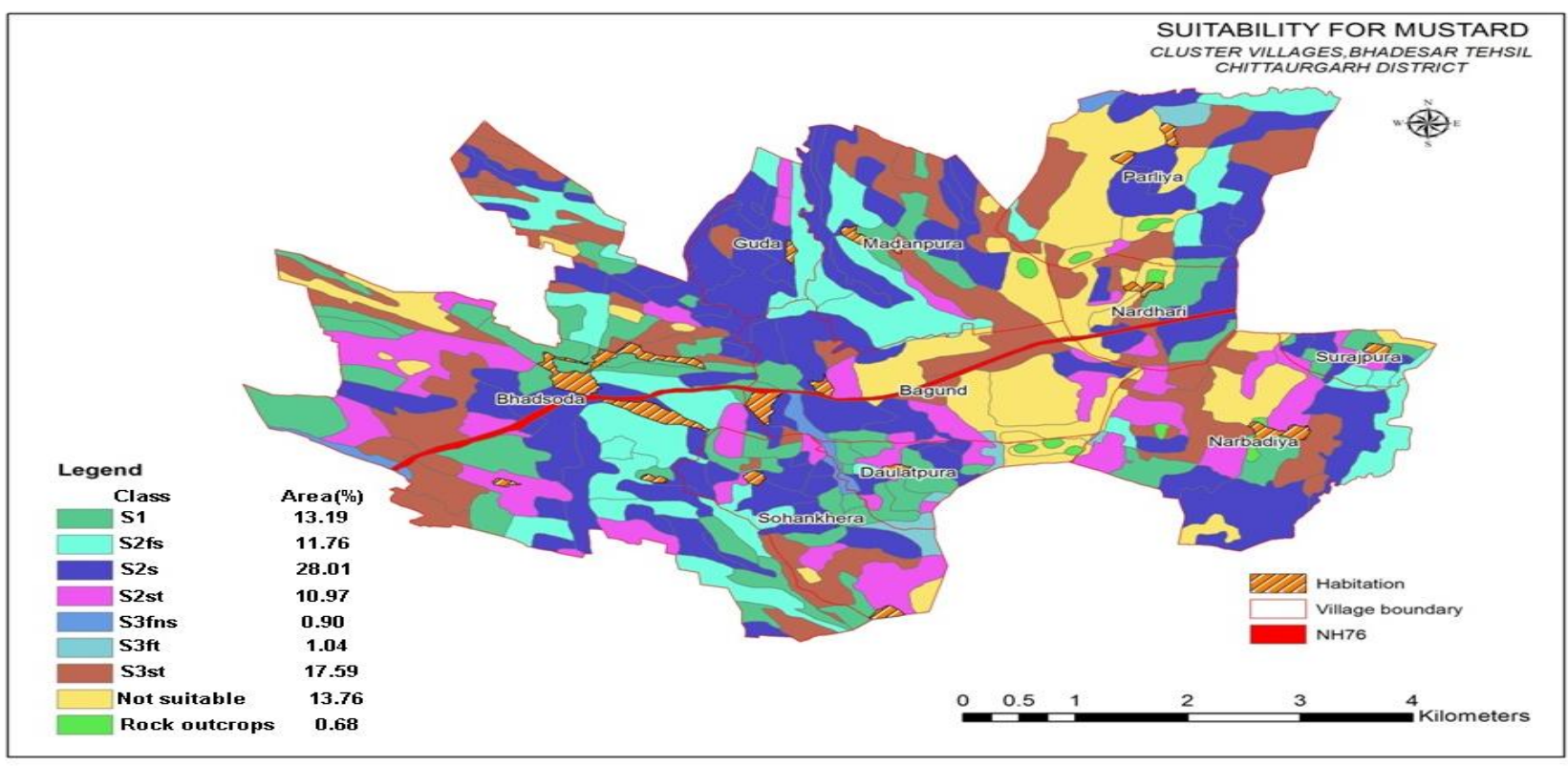

Fig.3. soil suitability map for mustard in cluster of Bhadesar tehsil

\section{Soybean (Glycine max)}

Soils of Daulatpura-c and d series are highly suitable without any constraint (Table 3 ). The soils of Bhadsoda-b, Nardhari-a and Nardhari-b are moderately suitable for soybean cultivation. Bhadsoda-b series have constraints of slope (3-8\%) and shallow depth of soil whereas Nardhari-a and Nardhari-b have shallow depth and low fertility constraints. Marginally suitable soils occur in Daulatpura-b, Bhadsoda-a, Bagund, Narbadiya-a, Narbadiya-b and Parliya series. Soils of Madanpura and daulatpura-a are not suitable for soybean cultivation due to very severe limitations of erosion with strong stoniness, excessive relief, excessively drained with rapid permeability, shallow depth, loamy skeleton texture. Similar results were reported by Naveen Kumar et al. (2018) and Hegdeet al. (2019). It is revealed that about $21 \%$ area of the cluster is highly suitable for cultivation of soybean without any limitation (Fig. 4).

Moderately suitable soil covers about $31 \%$ of area with major limitations of slope, depth, fertility and soil texture. Marginally suitable soils occupy about $30 \%$ of area with major limitation of slope, depth, severe erosion, gravelliness and low soil fertility. About $15 \%$ area is unsuitable for the cultivation of Soybean. 


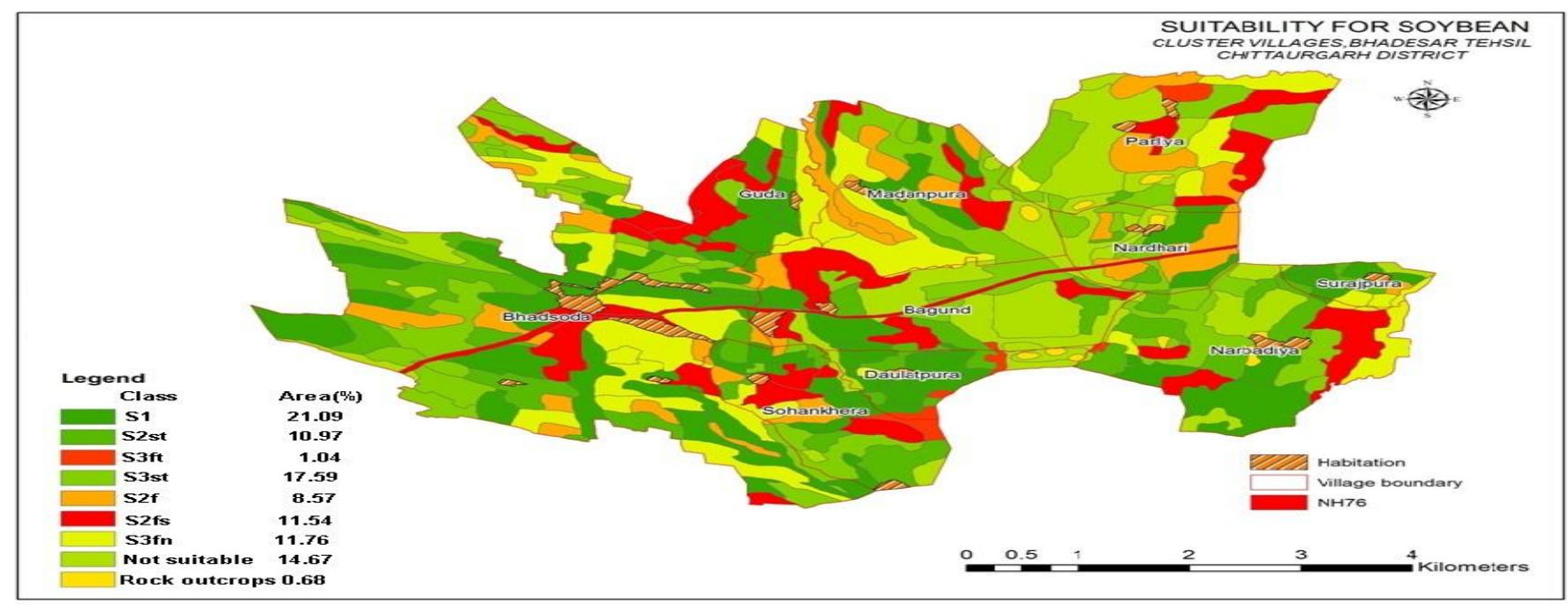

Fig-4. Soil suitability map for soybean in cluster of Bhadesar tehsil

\section{REFERENCES}

Gandhi, Gopal and Savalia, S.G. (2016) Soil-site suitability evaluation for wheat in calcareous basaltic soils of Girnar toposequence in Southern Saurashtra region of Gujarat.Journal of the Indian Society of Soil Science 64(1): 41-45.

Garhwal, R.S., Qureshi, F.M., Giri, J.D., Yadav, R.S. and Rameshwar Singh (2013) Suitability assessment for arable crops in Sirohi district of Rajasthan. Journal of the Indian Society of Soil Science 64(2): 143146.

Hegde, Rajendra., Bardhan, G., Niranjana, K.V., Bhaskar, B.P. and Singh S.K. (2019)Land evaluation for site-specific crop planning a case study of Chincholi Khurd-1 microwatershed, Aland taluk, Gulbarga district, Karnataka India. Journal of the Indian Society of Soil Science 67(3): 291300.

IARI (1971) Soil Survey Manual, All India Soil and Land Use Survey, IARI, New Delhi.

Jackson, M.L. (1973) Soil Chemical Analysis, Prentice Hall of India Private Ltd., New Delhi.

Mustafa, A.A., Man Singh, Ahmed, Nayan., Sahoo, R.N., Khanna, Manoj., Sarangi, A. and Mishra, A.K. (2016)Soil suitability analysis for crop planning in Kheragarah tehsil of Agra District, Uttar Pradesh. Journal of the Indian Society of Soil Science 64(4): 311-318.

Naveen Kumar, H.T., Basavaraj, K., Reddy, Sharan Bhoopal., Rajesh, N.L. and Chinchmalatpure, Anil R. (2018) Land evaluation of Dotikol micro-watershed in North Eastern transition zone of Karnataka. Journal of the Indian Society of Soil Science 66(1): 1-8

Soil Survey Division Staff (2000) Soil Survey Manual (Indian print), USDA Handbook No. 18, United States Government Printing Office, Washington DC.

Soil Survey Staff (2014) Keys to Soil Taxonomy, $12^{\text {th }}$ edition, USDA, Natural Resources Conservation Services, Washington DC.

Sys, Ir. C., Van Ranst, E., Debaveye, J. and Beernaert, F. (1991) Land Evaluation: Part II Methods in land Evaluation.Agricultural Pub.No.7, Brussels, Belgium, 247pp.

Sys, Ir. C., Van Ranst, E., Debaveye, J. and Beernaert, F. (1993) Land Evaluation: Part III Crop Requirements.Agricultural Pub No.7, Brussels, Belgium, 199pp. 